\title{
Project-Based Independent Study Capstone Course
}

\author{
Ronald W. Welch, PhD, $\mathrm{PE}^{1}$ and Allen C. Estes PhD, $\mathrm{PE}^{2}$ \\ ${ }^{1}$ Colonel, Associate Professor, Department of Civil and Mechanical Engineering, United States \\ Military Academy, West Point, NY 10996; PH (845) 938-4099; FAX (845) 938-5522; e-mail: \\ ronald.welch@usma.edu \\ ${ }^{2}$ Colonel, Associate Professor, Department of Civil and Mechanical Engineering, United States \\ Military Academy, West Point, NY 10996; PH (845) 938-4607; FAX (845) 938-5522; e-mail: \\ allen.estes@usma.edu
}

\begin{abstract}
This paper describes a unique project-based course used successful by the ABET-Accredited Civil Engineering Program at the United States Military Academy (USMA) to greatly enhance the academic program. The three general project classifications available within this senior course are service-based (i.e., USMA, the Army, local community, etc.), competition-based (i.e., steel bridge, concrete canoe, timber bridge, Big Beam), and research-based. The exceptional student work provided at little to no cost to the client has opened up a ground swell of service and research projects now constantly offered to the program coordinator by prospective clients. We believe these independent study projects are successful due to our students being prepared through openended design in nearly every course we offer and through some initial project-based learning in earlier courses.
\end{abstract}

The mix of these open-ended projects usually ensures that each student can list a minimum of 3-5 project choices that meet their individual needs for a challenging, yet rewarding academic experience. Approximately 90-98 percent of the senior CE majors each year choose to work on one of these open-ended projects. With 45 to $60 \mathrm{CE}$ majors graduating each year, it is easy to understand that one faculty member cannot advise the required $15-20$ projects each spring. So many, if not all, of the CE program's 17 faculty must buy-in to the project-based senior program from the onset.

It will be shown through student assessment that this form of experience not only challenges, but also motivates the students like no other aspect of their academic experience. The students are providing a solution to a real world problem for a real client. The assessment will show that the students find project-based learning demanding, but enjoyable and worthwhile because it forces them to push the boundaries of their knowledge through initiative, self-study, perseverance, and creativity.

\section{Introduction}

Initial ABET requirements for increased design coverage nudged our program to increase design in our senior courses and to develop an integrated, multi-discipline design experience. Program assessment led us to consider design throughout the curriculum even before the current ABET 2000 design considerations. The more experience the students have with the design process, even with partial design experiences, the more prepared students are to complete a major design experience and better understand the many moving parts/disciplines of real design. Therefore, design begins in our Statics course using the West Point Bridge Designer (WPBD) program after 
coverage of trusses. Even though the students have not been taught about material properties and how it affects performance, the WPBD program allows the students to design a truss bridge, load test it, determine the performance, and modify the design until they have the most economical structure for the given conditions. Through this process they are able to connect analysis to design during the initial analysis courses which facilitates better understanding of analysis/design in later courses. We have design in most of the required courses: strengths of materials, hydrology, soil mechanics, structural analysis, steel design, reinforced concrete design, and the capstone - design of structural systems. Additionally, there is design in many senior electives to include our independent study course. The design experience becomes more open-ended and creative as the student progresses through the curriculum, especially in the steel and reinforced concrete design courses, with culmination in a design of an entire structure (either steel, timber, concrete, etc.) that meets a long list of a real client's needs.

So what is project-based learning and how does it fit? It is defined by some as learning through projects to motivate student self-learning (construct own knowledge base), to establish connections with the real-world outside of the classroom through solving complex, multi-disciplinary problems, and to work in teams while making decisions on how to determine answers and solve problems (San Meteo, 2001; Kraft, 2000, LTSN Engineering, 2001). We have used narrowly defined projects in our mechanics, soils, analysis and hydrology courses to set the stage for our semester long projects in our steel, reinforced concrete, and of course, the capstone course. The independent study projects represent our best example of project-based learning.

For over 30 years, independent study projects have been offered to civil engineering students at USMA, but only to the top 2-3 students in the program. The projects focused on in-depth study in a specific civil engineering sub-discipline with the ultimate goal being greater student knowledge through self-study and occasional faculty guidance. In the mid-eighties, the ASCE steel bridge and concrete canoe competitions were added as yearly projects. It quickly became evident that the best team of students, those possessing hands-on skills, would not always come from the top tier of students. In fact, most of the students wanting to be part of these competitions were not in the top tier. Faculty were concerned whether these students would be self-starters and be able to complete the work required to design and then build the prototype for the competition -- all in one semester. By the end of the semester, most faculty advisors and students found the experience (project-based learning) to be exhilarating, challenging, and just plain different from the normal academic experience. It was a win-win situation!

Research and scholarship activities gained greater focus in the mid-nineties with the addition of civilian faculty at USMA, and soon all faculty were spending more time on research, a trend that is occurring at many primarily undergraduate colleges. The inclusion of undergraduates in research was a natural extension of faculty research and a welcome addition to the list of available studentcentered learning projects. At the same time, many faculty were involved heavily within their community and knew of potential service-based projects that would also challenge and educate the students. It became obvious that many students would love the opportunity to put their skills to work and produce a product that met a real need.

In the fall of 1999, we decided to expand the civil engineering independent study program to ensure that every senior CE major had the opportunity to participate in an open-ended projectbased learning experience. This course is in addition to the required capstone experience that all students must participate in (the required capstone course ensures that all four CE sub-disciplines are addressed in the project). Student assessment data from the handful of students who participated in the previous years highlighted the value of the experience and conveyed the excitement they felt in providing a service to a real client. Therefore, an expanded project list was 
developed consisting of the three general project classifications: service-based (i.e., USMA, the Army, local community), competition-based (i.e., steel bridge, etc.), and research-based. Another important key within these projects, besides being a project-based student learning experience, is thatall are client-based projects.

\section{Projects}

The Department of Civil and Mechanical Engineering is extremely proud of the variety and number of projects it offers students. Consideration is given to the complexity of each project so that the workload for each project will fall within an acceptable window and the number of projects available in all three areas ensures each CE major has the opportunity to participate in an open-ended project.

Many projects each year are associated with some type of national competition or provide a needed service to our local community. However, many students support research being conducted by the faculty, often in conjunction with Army Labs. The average project group size is two to four students. Each project requires contribution, cooperation, and expertise from every member of the team, while allowing maximum student, client, and faculty advisor interaction. Students enrolled in any independent study project must present an oral brief at the end of the semester on Projects Day (Welch, 2002) and submit a comprehensive written report at the end of the project.

\section{a. Community Service Projects}

Community service projects have been extremely valuable at educating the community about engineering and building ties with local organizations (Welch and Ressler, 2002). These local organizations and communities receive a valuable service from the students in the form of a design, a professional report, and/or a physical structure at a negligible cost. These organizations / communities have, in turn, informed other groups that have aggressively sought assistance from the department. Students learn to interact with community sponsors, many who have little technical training, and contribute to the local area in a meaningful way. Recent project sponsors ranged from sports clubs at the academy to a local humane society. Large funding requirements must come from the client, while small amounts, if the client has limited funds, come from our alumni organization, the Association of Graduates (AOG).

A complete list of community service projects and clients over the last five years are in Table 1 .

Table 1: Community Service Projects

\begin{tabular}{|l|l|}
\hline \multicolumn{1}{|c|}{ Community Service Project } & \multicolumn{1}{c|}{ Clients } \\
\hline \multicolumn{1}{|c|}{ Academic Year 1999-2000 } \\
\hline Constitution Island Bridges & $\begin{array}{l}\text { West Point and Constitution Island } \\
\text { Historical Society }\end{array}$ \\
\hline Popolopen Brook Bridge Feasibility Study & Mid-Hudson Valley Military Historian \\
\hline Cableway Training Kit & Fort Bragg \\
\hline $\begin{array}{l}\text { Large Area Maintenance Structures } \\
\text { Tie-down }\end{array}$ & Natick Labs \\
\hline Church Steeple Analysis & Newburgh Church \\
\hline Abatis Site & West Point Camp Buckner Training \\
\hline Bridge Demolition & West Point Camp Buckner Training \\
\hline
\end{tabular}




\begin{tabular}{|c|c|}
\hline Wall Breaching & West Point Camp Buckner Training \\
\hline \multicolumn{2}{|c|}{ Academic Year 2000-2001 } \\
\hline $\begin{array}{l}\text { West Point Lower Area Recreational } \\
\text { Complex }\end{array}$ & USMA Housing Office \\
\hline Walden Humane Society Renovation & Walden Humane Society \\
\hline Popolopen Brook Float Bridge & Fort Montgomery Battlefield Site Ass. \\
\hline Ground Water Study and Aquifer Model & USGS and Town of Gardiner, NY \\
\hline Structural Evaluation of Church Bell Tower & St. George's Church, Newburgh, NY \\
\hline Ice Jam Prediction Investigation & $\begin{array}{l}\text { Cold Regions Research \& Engineering } \\
\text { Lab }\end{array}$ \\
\hline Indoor Obstacle Course Load Testing & Department of Physical Education \\
\hline Project Wrench & Department of Civil and Mechanical Eng \\
\hline USMA Parking Analysis & Department of Civil and Mechanical Eng \\
\hline Rugby Facility Design & AOG, Army Rugby Team \\
\hline \multicolumn{2}{|c|}{ Academic Year 2001-2002 } \\
\hline Catholic Chapel Annex & West Point Catholic Community \\
\hline Appalachian Trail Foot Bridge & Palisades Park Commission \\
\hline Wallkill Library Expansion & Town of Wallkill \\
\hline $\begin{array}{l}\text { Rehabilitation of Peace Bell Structure @ } \\
\text { Washington's Last Encampment }\end{array}$ & Town of New Windsor \\
\hline MOUT Site & West Point Camp Buckner Training \\
\hline 5-Story Skyscraper - Leader Reaction Course & West Point Camp Buckner Training \\
\hline Weir/Bridge Design - Class '43 Gift Site & West Point Class of 1943 \\
\hline Stillwell Dam Flood Study & West Point and Town of Fort Montgomery \\
\hline Stillwell Dam Assessment & West Point \\
\hline Trebuchet & Department of Civil and Mechanical Eng \\
\hline \multicolumn{2}{|c|}{ Academic Year 2002-2003 } \\
\hline Homeland Security Master Plan & Joint Task Force 6 \\
\hline Transportation Motor Pool Foot Bridge & West Point \\
\hline Wallkill Library Expansion & Town of Wallkill \\
\hline Scaled Masonry Building & Department of Civil and Mechanical Eng \\
\hline $\begin{array}{l}\text { The West Point K'Nexercise - Interactive } \\
\text { Construction Management Experience }\end{array}$ & Department of Civil and Mechanical Eng \\
\hline Wind Tunnel Foundation Design & Sport Parachute Team \\
\hline Project Wrench & Department of Civil and Mechanical Eng \\
\hline Galveston District Flood Study & Galveston District \\
\hline Bear Mountain Flood Study & Palisades Park Commission \\
\hline \multicolumn{2}{|c|}{ Academic Year 2003-2004 } \\
\hline Redoubt Observation Platforms & West Point \\
\hline Restoration of Kosciuszko's Garden Area & West Point \\
\hline Historic Water Tower Assessment & New York State Parks, Jones Beach Park \\
\hline Youth Center Pedestrian Bridge & West Point Youth Center \\
\hline West Point Foundry Site Layout & Scenic Hudson Valley \\
\hline Bear Mountain Storm Water Study & Palisades Park Commission \\
\hline Homeland Security Training Facility & Picatinny Arsenal \\
\hline Border Patrol Road Design & Joint Task Force 6 \\
\hline Infrastructure Assessment Tools & Construction Engineering Research Lab \\
\hline
\end{tabular}

\section{b. Competition Projects}


Competition projects are conducted at regional and national levels. Funding for these projects is primarily through our alumni organization, AOG, and donations of skills, equipment, and materials from interested sponsors/clients, such as PDJ Components associated with the Timber Bridge Competition (Nakano and Vander Schaaf, 2001a and 2001b). These design, build, and compete projects usually involve various technologies and bring out the best effort in our students. Students become very knowledgeable about their building material and construction practices, and they develop well structured and organized competition design teams. Competition projects are highly desirable for many students since they are competitive by nature, but traveling and winning are high on the list as well. The ability to travel and participate in the national competition is always dependent on the quality and progress of their product. Teamwork and project management skills go a long way in these major design projects.

A complete list of competition projects is in Table 2.

Table 2: Competition Projects

\begin{tabular}{|l|l|}
\hline \multicolumn{1}{|c|}{ Competition Project } & \multicolumn{1}{c|}{ Clients } \\
\hline AISC Steel Bridge Competition & AOG $(2000,2001,2002,2003,2004)$ \\
\hline ASCE Concrete Canoe Competition & AOG (2000, 2001, 2002, 2003, 2004) \\
\hline ASCE National Timber Bridge Competition & AOG (2001, 2002, 2003, 2004) and PDJ \\
& Components and Roe Brothers (2001, \\
& 2003) and Hoover Treated Wood \\
& Products (2002) \\
\hline ACI Big Beam & AOG (2004), Oldcastle Precast (2004) \\
\hline
\end{tabular}

\section{c. Research Projects}

Research projects give students an excellent opportunity to participate in existing research at an Army laboratory or with USMA faculty members (Conley et. al., 2001). Many of these projects allow students to have access to data and computing facilities not available at USMA. Some research project sponsors are not even in our local area, but an initial visit to the laboratory, constant communication (usually through e-mail and teleconferencing), and any necessary follow up visits with the sponsor at West Point usually provides sufficient direction. Often, the client organization can provide the required travel funds for the students to visit the lab. Many of these projects allow our students to influence new Army technology that they may use after they graduate and enter the Army.

A complete list of research projects and clients from the past five years are in Table 3.

Table 3: Research Projects

\begin{tabular}{|c|c|}
\hline Research Project & Clients \\
\hline \multicolumn{2}{|c|}{ Academic Year 1999-2000 } \\
\hline Frost/Heave & Cold Regions Lab \\
\hline Strengthening RC Beams with FRP & Army Research Laboratory \\
\hline Ice Jam Prediction Investigation & $\begin{array}{l}\text { Cold Regions Research \& Engineering } \\
\text { Lab }\end{array}$ \\
\hline \multicolumn{2}{|c|}{ Academic Year 2000-2001 } \\
\hline Prioritizing Repair Projects -Locks and Dams & Construction Engineering Research Lab \\
\hline
\end{tabular}




\begin{tabular}{|c|c|}
\hline Carbon Fiber Reinforced Plastics & Army Research Laboratory \\
\hline Modal Analysis of Blast Plates & Army Research Laboratory \\
\hline Watershed and Reservoir Study & Waterways Experiment Station \\
\hline $\begin{array}{l}\text { Large Area Maintenance Shelter } \\
\text { Foundation Design }\end{array}$ & Natick Labs \\
\hline Mine Vehicle & Army Research Laboratory \\
\hline Ice Jam Prediction Investigation & $\begin{array}{l}\text { Cold Regions Research \& Engineering } \\
\text { Lab }\end{array}$ \\
\hline \multicolumn{2}{|c|}{ Academic Year 2001-2002 } \\
\hline Reliability Analysis of Miter Gates & Construction Engineering Research Lab \\
\hline Lightweight Concrete Modulus of Elasticity & Noorlite \\
\hline Retrofit of Steel Structures with FRP & Army Research Laboratory \\
\hline $\begin{array}{l}\text { Small Arms Penetration into } \\
\text { Geologic Materials }\end{array}$ & $\begin{array}{l}\text { Army Engineering Research \& } \\
\text { Development Center }\end{array}$ \\
\hline L Design Charts for Laterally Restrained Slabs & Department of Civil and Mechanical Eng \\
\hline \multicolumn{2}{|c|}{ Academic Year 2002-2003 } \\
\hline Blast Load Primer & Army Research Laboratory \\
\hline $\begin{array}{l}\text { Soil Constitutive Modeling to Predict } \\
\text { Trafficability }\end{array}$ & Cold Regions Laboratory \\
\hline $\begin{array}{l}\text { Develop Material Properties for High } \\
\text { Strength Low Weight Concrete }\end{array}$ & Department of Civil and Mechanical Eng \\
\hline Progressive Collapse & Department of Civil and Mechanical Eng \\
\hline \multicolumn{2}{|c|}{ Academic Year 2003-2004 } \\
\hline Blast-Resistant Power Transmission Towers & $\begin{array}{l}\text { Army Engineering Research \& } \\
\text { Development Center }\end{array}$ \\
\hline $\begin{array}{l}\text { Predicting the Modulus of Elasticity of } \\
\text { Lightweight Concrete }\end{array}$ & Department of Civil and Mechanical Eng \\
\hline
\end{tabular}

\section{Assessment}

Client-based open-ended projects provide a wonderful opportunity for students to use all their skills to creatively solve a problem, while allowing the faculty another opportunity to assess whether the students have met course and even ABET requirements. We have assessed the effectiveness of our projects principally through the use of our institution's course-end feedback system. This system is administered entirely over the worldwide web and features a small number of USMA-standard survey questions, supplemented by department-specific and course-specific questions of our own choosing. Students respond to these questions using a scale of 1 (strongly disagree) to 5 (strongly agree). For the USMA-standard questions, this system allows us to compare our own students' survey responses to those of all other students at USMA taking more traditional courses, i.e., not independent studies. More importantly, the inclusion of coursespecific questions allows us to survey our students about their achievement of specific course objectives.

On their course-end feedback, the students have been extremely supportive of completing openended projects, especially for a real client. Relevant data are provided in Figures 1-3. Fig 1 shows CE489 (client-based project-based course listing) student responses to USMA-standard questions that relate specifically to the quality of instruction and student learning; nonetheless, we also believe these particular responses also reflect student satisfaction with the course described in this paper. Baseline values are averages for CE489 and USMA-wide responses over the last five years. The USMA baseline responses have been extremely stable over time. In 2003, we had two projects 
with extremely low scores on the USMA questions. The advisors for these two projects were not able to provide the type of support the students felt was necessary; they just were not available. Even though this is an independent study, some students still want to discuss ideas with faculty

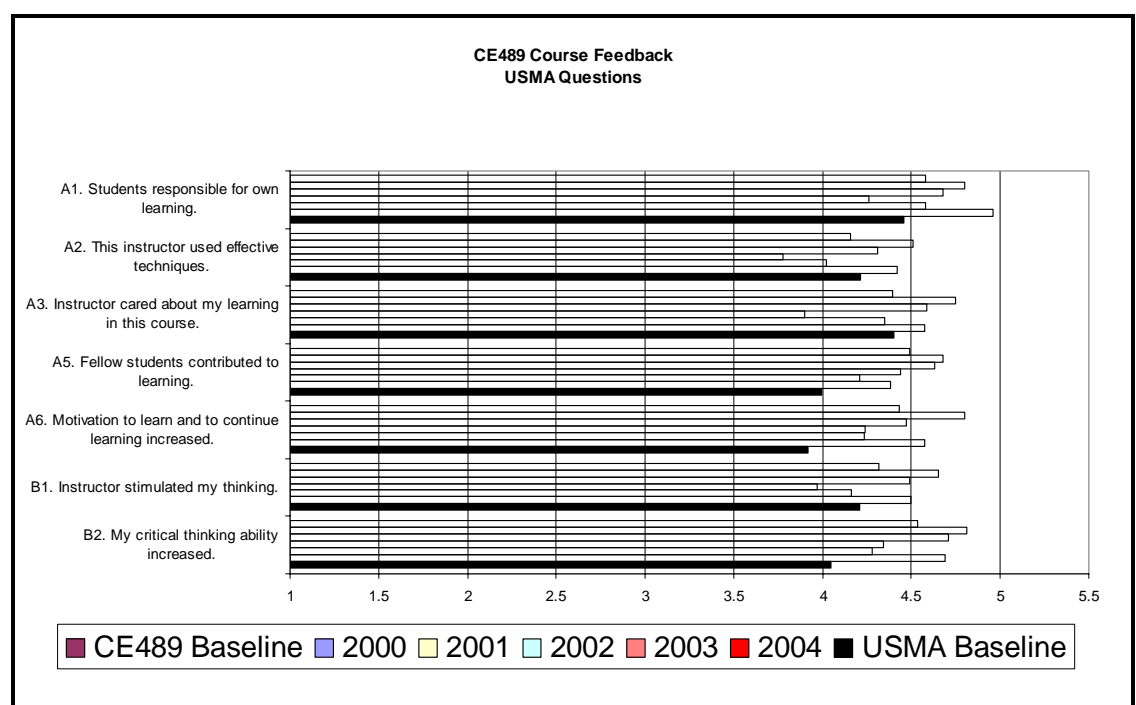

Figure 1. CE489 Course Feedback

and occasionally receive guidance. Earlier it was mentioned that there is a need for total faculty buy-in. In this case the faculty were focused elsewhere. However, overall feedback is phenomenal considering that the students only meet once a week with the faculty advisor. Even though some of the students were not happy with the support from the advisor, the student's felt they accomplished (Fig. 2) the course objectives. Even in 2003, the lowest value was near 4.0 which indicates substantial agreement with the statement. The course objectives for CE489 are broader, less defined and more difficult to accomplish than with a traditional course. The high average response reflects a high level of overall confidence in the course meeting their specific learning needs. Comparison of 2004 feedback for the USMA questions against other traditional senior civil

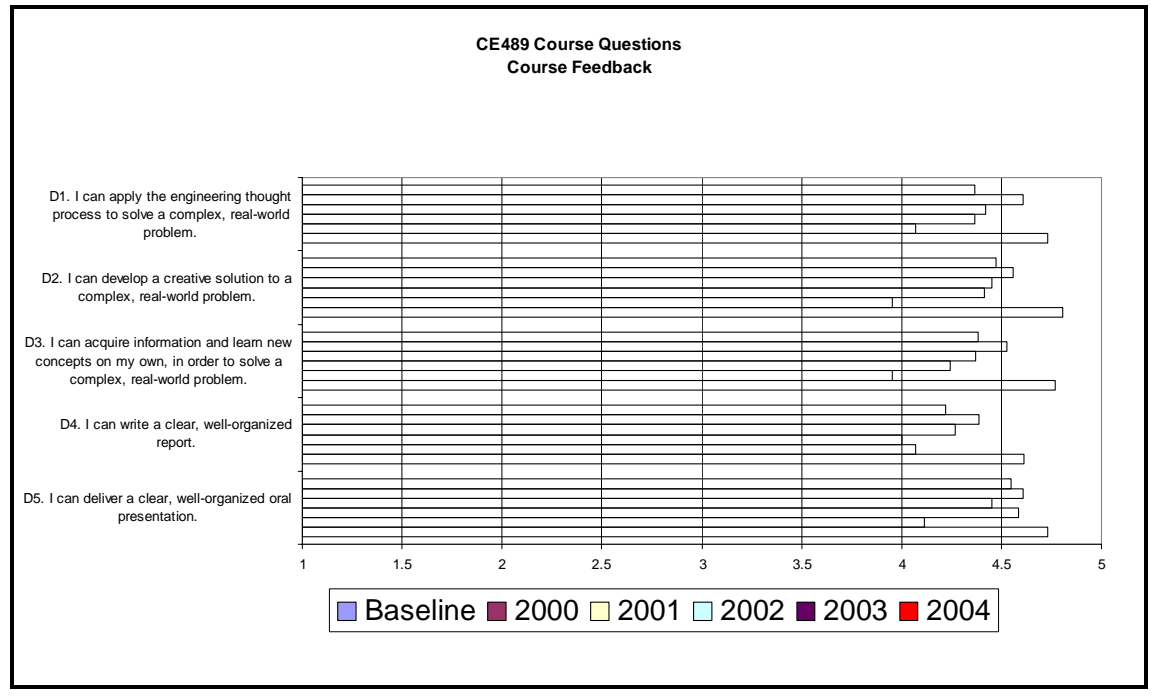

Figure 2. CE489 Course Specific Feedback 
engineering courses with the same general student population (Fig. 3; CE404 - Design of Steel Structures; CE483 - Design of Reinforced Concrete; CE491 - Advanced Structural Analysis, CE492 - CE Capstone Course, Design of Structural Systems), we see that this type of course is well received by the students. The student-teacher relationship can be quite difficult for an independent study course. The amount of contact time is less, but the instruction and guidance is more personalized.

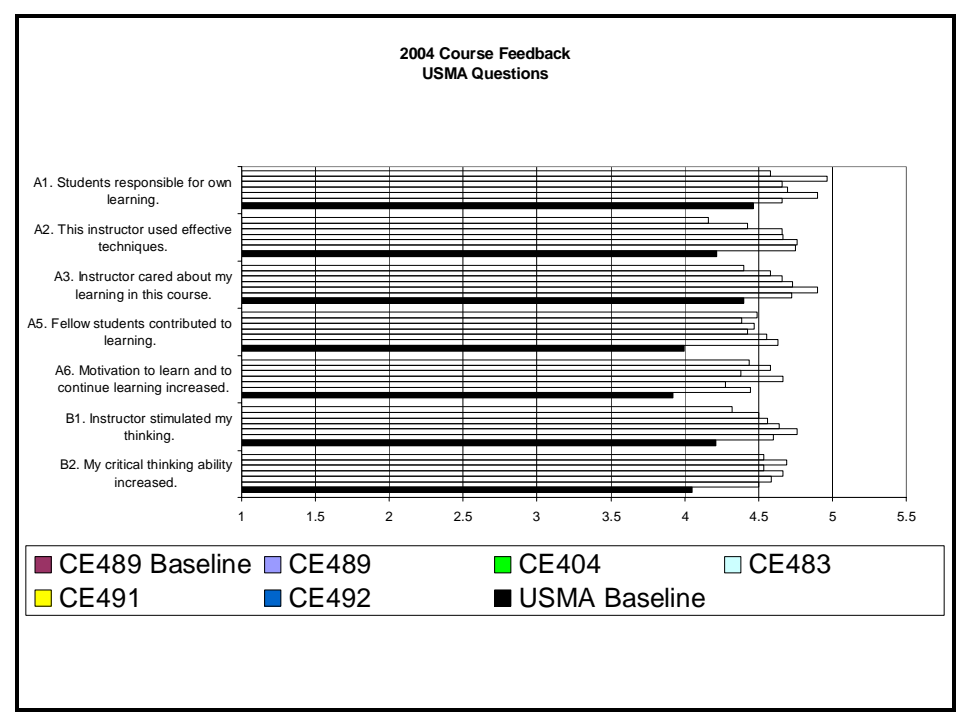

Figure 3. 2004 Course Feedback

The next logical question is how well do the different types of projects (service-based, competition-based, and research-based) in CE489 actually compare to one another? Competition projects have a defined end point - a product that can compete at the regional conference. Service projects generally have an envisioned physical product from the beginning or a design that helps the client in their decision making process. On the other hand, research projects do not always have as clearly defined end point and may only be one piece of a multi-year study. As shown in Figure 4 (Term 01-2), the three different types of projects received similar feedback results. When

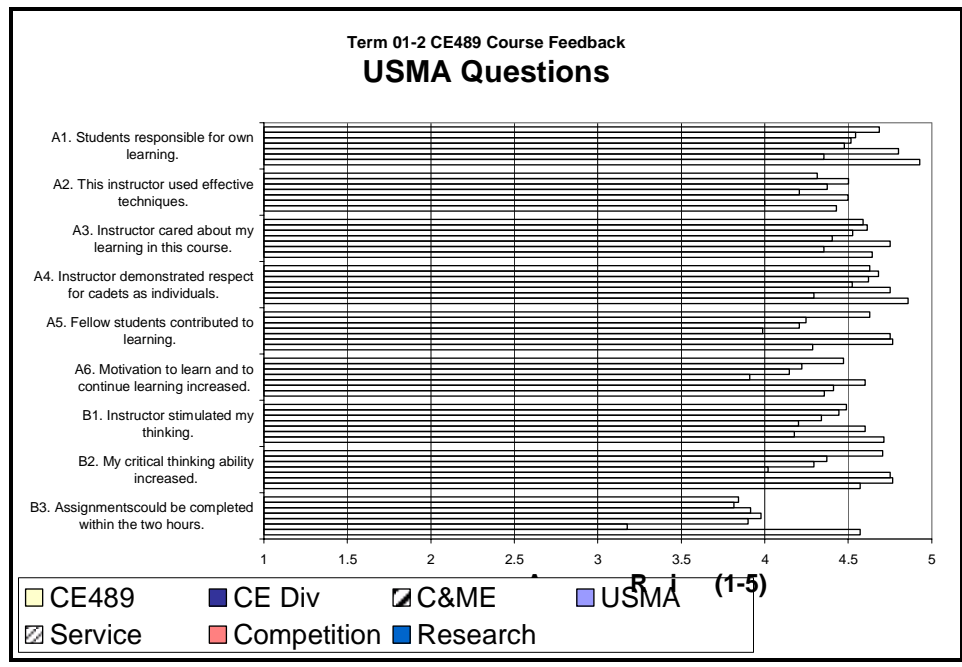

Figure 4. CE489 Term 01-2 Course Feedback 
looking at Figures 5-7 for the following three academic years, the competitions were rated lower than other projects in Terms 01-2 thru 03-2, but saw a strong rebound in Term 04-2. Given the high numbers on the annual composite ratings (consistently above 4.0), it only takes one or two disgruntled students to affect the rating. Independent study projects tend to be less structured and higher risk, so the chance of one student having a really bad experience increases. Most projects require creativity, initiative, and innovation which many students are not as prepared to initially execute themselves. When faculty do not have the solution or if the project is not fully defined at the beginning of the semester, some students are initially uncomfortable. However, most overcome and enjoy the added freedom of choice. Overall, the three types of projects provide a different experience for each grouping of students while at the same time requiring the student to produce a solution to a client-based open-ended independent study project.

In response to the "free text" question, "what did you learn from the course", a few of the student responses follow:

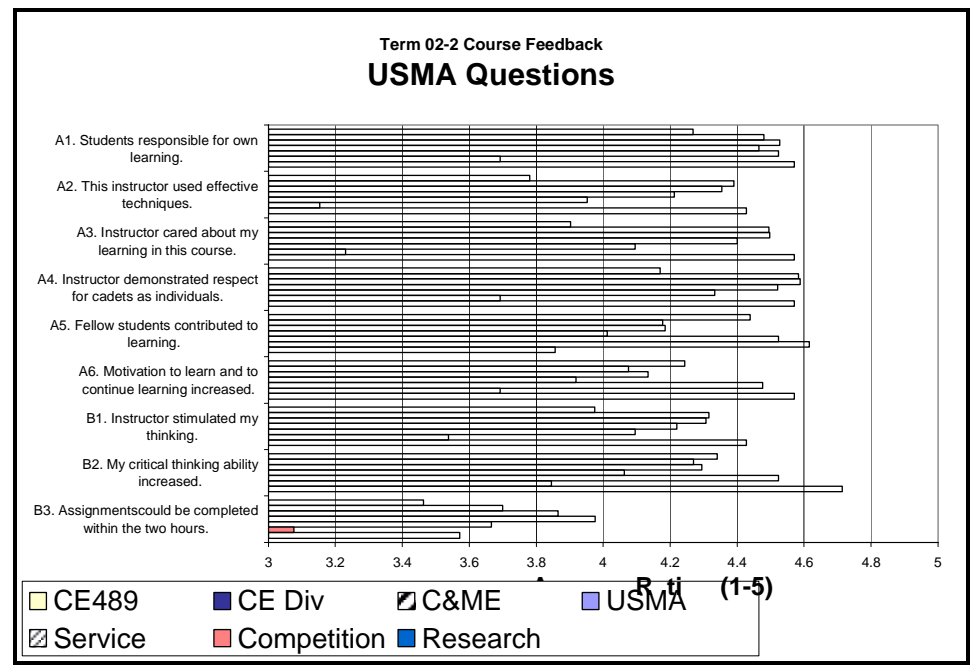

Figure 5. CE489 Term 02-2 Course Feedback

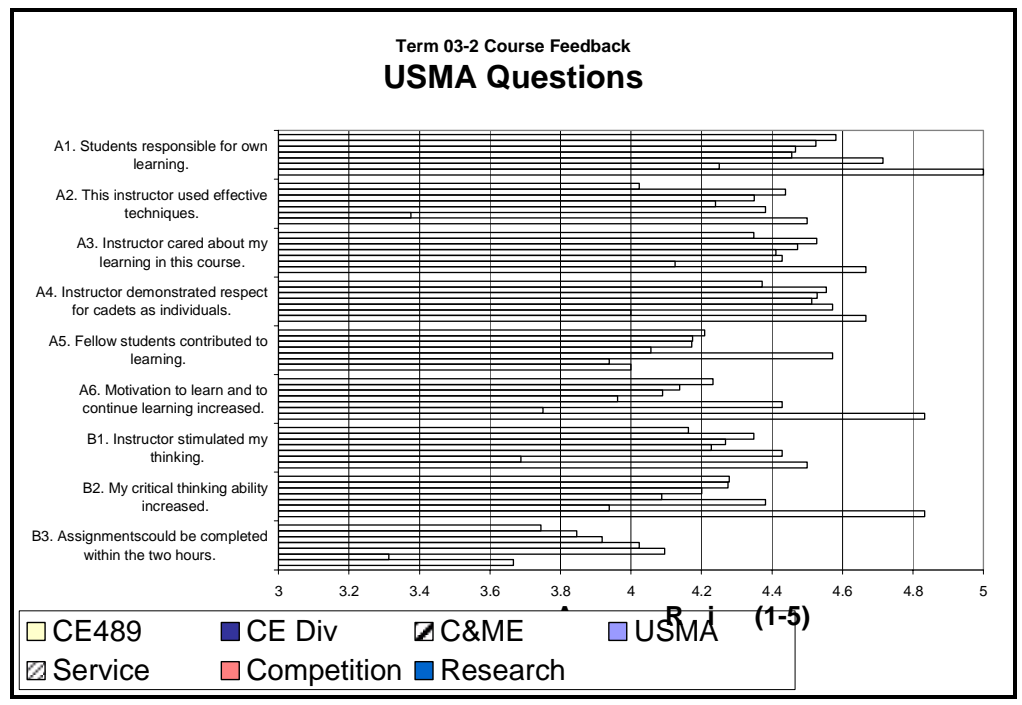

Figure 6. CE489 Term 03-2 Course Feedback 


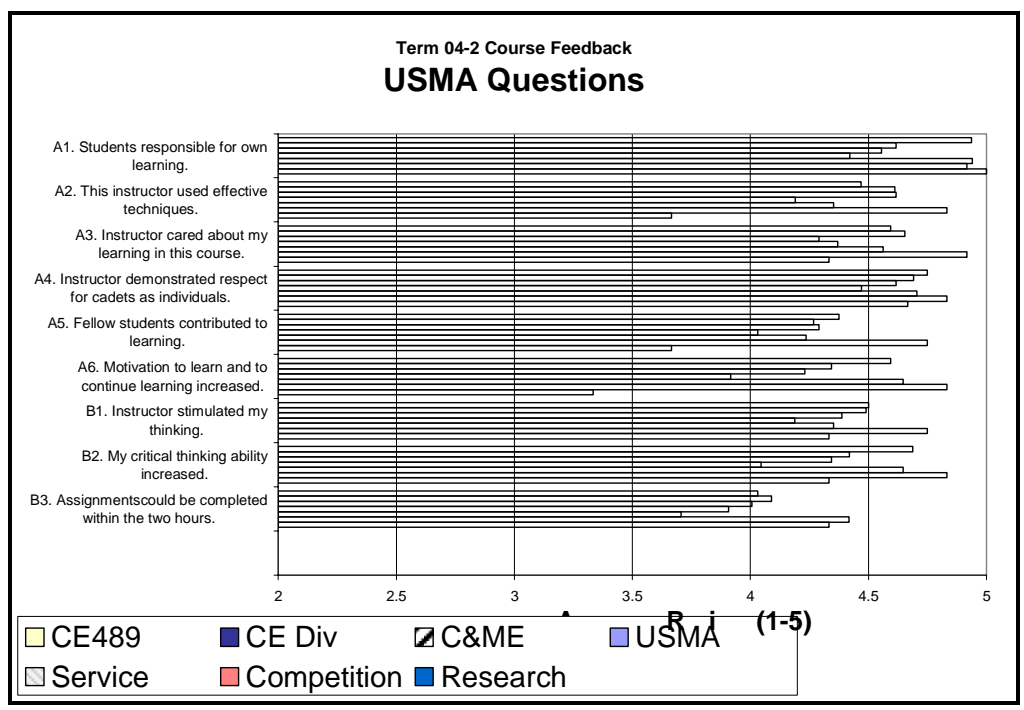

Figure 7. CE489 Term 04-2 Course Feedback

- I feel that this course was the perfect completion of my undergraduate education in civil engineering. I learned a great deal about what it takes to put together a project from ground zero to the preliminary design. It was perfectly tailored for what I need to learn.

- Students can make a difference.

- We have the knowledge to solve real-world problems.

- I know more than I thought I did about engineering and the problem solving methodology.

- I learned that there is much more to civil engineering than what I have learned in formal training.

- Working on an ambiguous project is more time consuming than other projects here.

- How to think outside of the box.

- That real-world problems require in-depth thinking and problem solving and that the skills I have learned earlier in my student career are actually applicable.

- My designs will work in real life and I am capable of designing something that works.

- A designer MUST take into consideration constructability.

- There are so many points in a project to get stopped or distracted. I learned how to anticipate them and react to them.

- I enjoyed learning how to "sell" an idea.

One student appropriately summarized the learning experience as follows:

"I learned more in this course than any other I have taken in the program."

Many other comments emphasized how much students valued being involved with real engineers, customers, and projects.

Projects Day itselfprovides an opportunity to assess the curriculum (Welch, 2002; DPOM, 2001). ABET 2000 Criterion 3(g) states that graduates must have an ability to communicate effectively (Dean's Policy, 2001). Clients receive a written product and a formal brief either at Projects Day or at the clients' business. Having spent at least a semester on a project, most design groups are so familiar with entire project that preparation for the presentation was really not a huge burden considering all the required information is in the completed report. Figure 2, Question D5 is an objective assessment measuring the students' confidence to present their capstone project. 
Faculty advisors also receive informal feedback from the clients. Most have reported enjoying working with the students and receiving a valuable product in return. Most of the sponsors volunteered again and many clients solicited the students' assistance in subsequent years, which is further evidence of their satisfaction with the program. In fact, the Popolopen Brook Bridge project was a multiple year project based on the quality of the work the first year (Welch and Ressler, 2002). The excitement for the product displayed in Figure 8 drew in representatives from the New York Bridge Authority who were extremely impressed with the creativity displayed. The more permanent bridge, a cable-stayed suspension bridge, constructed by the New York Bridge Authority had its genesis in the work completed by the first student working on the bridge design.

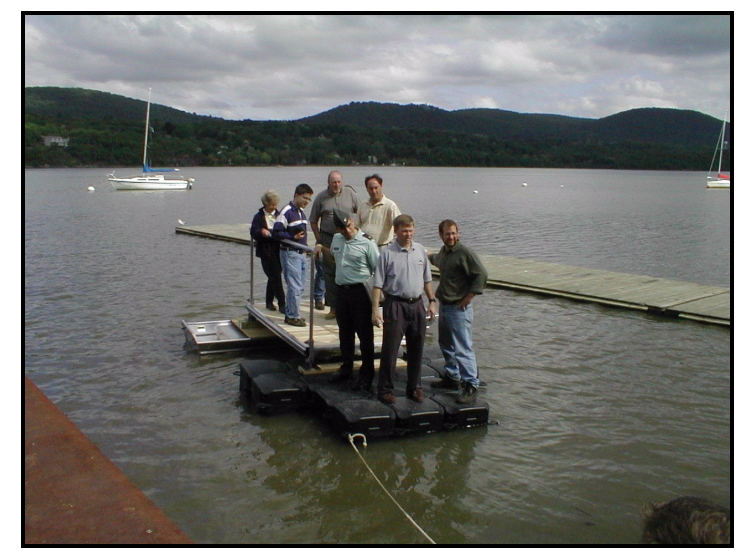

Figure 8. Float Bridge Full Scale Module Demonstration on the Hudson River

As stated above, the faculty advisors are essential to the success of projects from year to year. The independent study projects are not a free activity. There is a substantial cost in terms of time and effort that faculty could spend on other activities. While the goal is for the student to do the work, the faculty advisor often needs to intervene to keep the project moving. Many faculty have questioned whether the program is worth the effort, especially when first-year instructors who are still learning to teach must participate. In faculty surveys, we assessed the cost benefit ratio to be around 1.0. The student derives a huge benefit but requires a significant contribution from the faculty. We have asked ourselves whether we can afford to continue this program given its cost. We have concluded that how can we afford to not continue it given its unique benefit that students receive from no other course.

\section{Conclusion}

The students are providing solutions to real world problems for real clients. The reverse is also true, student involvement in solving the mix of problems and/or designing/building products stimulate the clients and sponsors to become heavily involved during the process. Increased client participation enhances not only the quality of the product, but the experience for the student and client. These semester-long project-based learning experiences benefit all, including the faculty. The assessment shows that the students find the program demanding, but enjoyable and worthwhile because it forces them to push the boundaries of their knowledge through initiative, self-study, perseverance, and creativity through open-ended project-based courses. 


\section{Acknowledgements}

The opinions and conclusions presented is this paper are those of the writers and do not necessarily reflect the view of the sponsoring organizations.

\section{References}

ABET. (2002). Criteria for Accrediting Engineering Programs. 〈http://www.abet.org>

Conley, C.H., Leamy, M.J., Choi, Y.Y. and Hurst, H.C. (2001). "Finite Element Model Refinement Using Experimental Modal Analysis." Proceedings of the 72nd Shock \& Vibration Symposium. Destin, FL. 12-16 November, 2001.

Conley, C.H., Choi, Y.Y., Hurst, H.C., Leamy, M.J., Gregory, F.H., and Gniazdowski, N.M.. (2001). "Modeling of Blast-Loaded Structural Panels - Continued." Proceedings of the 9th Annual ARL/USMA Technical Symposium. Aberdeen Proving Ground, MD and West Point, NY. 5\&7 November, 2001.

DPOM (2001). Dean's Policy and Operating Memorandum 02-30, Office of the Dean, United States Military Academy, West Point, New York, 2001.

Kraft, N. (2000). "Criteria for Authentic Project-Based Learning." RMC Research Corporation. <www.rmcdenver.com/useguide/pbl.htm>

LTSN Engineering. (2001). "Project-Based Learning in Engineering." Funded by Higher Education Funding Council for England. <www.pble.ac.uk/about-pble.html>

Nakano, V.M., and Vander Schaaf, R.E. (2001a). “Academics and Industry: A Win-Win Situation.” The Lumber Co-Operator. Aug-Sep 2001. p.14.

Nakano, V.M., and Vander Schaaf, R.E. (2001b). “Community Spirit.” Woodwords. Aug 2001. p.52.

Welch, R.W. (2002). "Client-Based Service Projects - A Mark of Excellence For Any Program." Proceedings of the 2002 American Society for Engineering Education Zone I Conference. American Society for Engineering Education. April 2002. West Point. Session C.

Welch, R.W. and Ressler, R.J. (2002). "Popolopen Brook Float Bridge Project - Integrating History, Community Service and Engineering Education." Proceedings of the 2002 American Society for

Engineering Education Annual Conference. American Society for Engineering Education. June 2002. Session 2215.

San Meteo County Office of Education. (2001). "Project-Based Learning with Multimedia." <pblmn.k12.ca.us/PBLGuide/Why PBL.html> 